\title{
ANALISIS FAKTOR-FAKTOR YANG MEMPENGARUHI KINERJA TENTARA NASIONAL INDONESIA DI KOMANDO DISTRIK MILITER 0618/BS KOTA BANDUNG
}

\section{ANALYSIS OF FACTORS INFLUENCING THE INDONESIAN NATIONAL ARMY PERFORMANCE IN 0618/BS MILITARY DISTRICT COMMAND BANDUNG CITY}

\author{
Farida Nuraeni Yusuf ${ }^{*}$, R. Ira Irawati2 ${ }^{2}$, Mas Halimah ${ }^{3}$ \\ 1,2,3Universitas Padjadjaran, Bandung, Jawa Barat, Indonesia \\ *Korespondensi: Farida Nuraeni Yusuf. Email: faridanury@gmail.com
}

(Diterima: 12-06-2019; Ditelaah: 24-06-2019; Disetujui: 03-07-2019)

\begin{abstract}
The Indonesian National Army performance in 0618/BS Military District Command of Bandung City is influenced by many factors. The purpose of this research is to find out the most dominant factors influencing the Indonesian National Army performance in 0618/BS Military District Command of Bandung City. The method of this research is the mixed method that the researchers use two methods, namely quantitative and qualitative methods. The techniques of data collection are observation, questionnaires using Likert's scale, interview, and literature study. In this research, the researchers analyze five factors, namely personal factor, leadership factor, team factor, system factor, and contextual factor. Based on five factors, the results of the analysis indicate that the most dominant factor is the personal factor. It means that the Indonesian National Army is an idealized work and the members of the Indonesian National Army happily conduct the work. Moreover, the second factor that dominantly influences the performance is the leadership factor. It means that the leader mostly influences the Indonesian National Army performance in 0618/BS Military District Command.
\end{abstract}

Keywords: Employee Performance, Performance Factors, TNI.

\begin{abstract}
ABSTRAK
Kinerja Tentara Nasional Indonesia di Komando Distrik Militer 0618/BS Kota Bandung dipengaruhi oleh banyak faktor. Tujuan penelitian ini adalah untuk mengetahui faktor yang paling dominan mempengaruhi kinerja Tentara Nasional Indonesia di Komando Distrik Militer 0618/BS Kota Bandung. Metode yang digunakan dalam penelitian ini adalah mixed method dimana peneliti menggunakan dua metode sekaligus yaitu kuantitatif dan kualitatif. Teknik pengumpulan data yang digunakan adalah observasi, kuesioner yang menggunakan skala Likert, wawancara, dan studi kepustakaan. Dalam penelitian ini, peneliti menganalisis lima faktor, yaitu personal factor, leadership factor, team factor, system factor, dan contextual factor. Berdasarkan lima faktor tersebut, hasil analisis menunjukkan bahwa faktor yang paling dominan adalah personal factor. Hal ini berarti bahwa TNI adalah pekerjaaan yang telah dicita-citakan sehingga secara tidak sadar anggota-anggota TNI tersebut senang melakukan pekerjaan dimaksud. Selain itu, faktor kedua yang dominan mempengaruhi kinerja adalah leadership factor yang artinya pemimpin sangat mempengaruhi kinerja TNI di Komando Distrik Militer 0618/BS.
\end{abstract}

Kata Kunci: Kinerja Pegawai, Faktor Kinerja, TNI.

Farida Nuraeni Yusuf. 2019. Analisis Faktor-faktor yang Mempengaruhi Kinerja Tentara Nasional Indonesia di Komando Distrik Militer 0618/BS Kota Bandung. 


\section{PENDAHULUAN}

Organisasi seperti halnya Tentara Nasional Indonesia (TNI) di Komando Distrik Militer 0618/BS Kota Bandung dibentuk untuk mencapai tujuan bersama, namun untuk mencapai tujuan secara efektif diperlukan manajemen yang baik dan benar. Dalam hal ini, manajemen merupakan proses untuk membuat aktivitas terselenggara secara efisien dan efektif dengan dan melalui orang lain.

Kinerja seseorang dalam organisasi, termasuk TNI, tidak dapat diukur secara kasat mata. Diperlukan indikator-indikator yang dapat dinilai atau diukur. Apa faktor yang mempengaruhi kinerja tersebut? Bagaimana pengaruhnya? Moorhead dan Chung Megginson (Siagian, 2009: 15) mengemukakan tujuh indikator untuk mengukur kinerja karyawan secara individu, yaitu kualitas pekerjaan, kuantitas pekerjaan, pengetahuan pekerjaan, kerja sama tim, kreativitas, inovasi, dan inisiatif. Dari indikator-indikator tersebut, kinerja dapat diukur dari tingkat kehadiran, ketepatan waktu dalam mengerjakan tugas dan efektivitas kerja di kantor.

\section{MATERI DAN METODE}

\section{Konsep/Teori yang Relevan}

Proses kinerja organisasional dipengaruhi oleh banyak faktor. Hersey, Blanchard, dan Johnson menggambarkan hubungan antara kinerja dengan faktorfaktor yang mempengaruhi dalam bentuk satelite model. Berdasarkan satelite model, kinerja organisasi diperoleh terjadinya integrasi dan faktor-faktor pengetahuan, sumber daya bukan manusia, posisi strategis, proses sumber daya manusia dan struktur. Kinerja dilihat sebagai pencapaian tujuan dan tanggung jawab bisnis dan sosial dari perspektif pihak yang mempertimbangkan (Wibowo, 2011: 98).

Pendapat lain tentang faktor-faktor yang mempengaruhi kinerja, antara lain dikemukakan Amstrong dan Baron dalam Wibowo (2011: 100), sebagai berikut: a. Personal factors, ditunjukkan oleh tingkat keterampilan, kompetensi yang dimiliki, motivasi dan komitmen individu.

b. Leadership factors, ditentukan oleh kualitas dorongan, bimbingan, dan dukungan yang dilakukan manajer dan team leader.

c. Team factors, ditunjukkan oleh kualitas dukungan yang diberikan oleh rekan sekerja.

d. System factors, ditunjukkan oleh adanya sistem kerja dan fasilitas yang diberikan organisasi.

e. Contextual factors, ditunjukkan oleh tingginya tingkat tekanan dan perubahan lingkungan internal dan eksternal.

Potter dan Lawler berpendapat bahwa kinerja merupakan fungsi dari keinginan melakukan pekerjaan, keterampilan yang perlu untuk menyelesaikan tugas, pemahaman yang jelas atas apa yang dikerjakan dan bagaimana mengerjakannya. Dengan demikian, dapat dirumuskan model persamaan kinerja $=\mathrm{f}$ (keinginan melakukan pekerjaan, keterampilan, pemahaman apa dan bagaimana melakukan). Sementara itu, Lorsch dan Laurence menggunakan pemahaman bahwa kinerja adalah fungsi atribut individu, organisasi, dan lingkungan sehingga dirumuskan model persamaan kinerja $=\mathrm{f}$ (atribut individu, organisasi, lingkungan).

\section{Metode}

Metode yang digunakan dalam penelitian ini adalah metode gabungan (mixed methods) dari Creswell (2010: 5). Dalam hal ini, Sugiyono (2011: 404) mengatakan bahwa metode penelitian kombinasi (mixed methods) adalah suatu metode penelitian yang mengkombinasikan atau menggabungkan antara metode kuantitatif dengan metode kualitatif untuk digunakan secara bersama-sama dalam suatu kegiatan penelitian, sehingga diperoleh data yang lebih komprehensif, valid, reliabel dan obyektif. 


\section{HASIL DAN PEMBAHASAN}

\section{Karakteristik Responden}

Dari hasil kuisioner diperoleh informasi tentang karakteristik 69 orang yang merupakan sampel dalam penelitian ini. Adapun karakteristik responden tersebut sebagai berikut:

Tabel 1. Karakteristik Responden Berdasarkan Jenis Kelamin

\begin{tabular}{lll}
\hline Jenis Kelamin & $\begin{array}{l}\text { Frekuensi } \\
\text { (Orang) }\end{array}$ & $\begin{array}{l}\text { Persentasi } \\
(\%)\end{array}$ \\
\hline Laki-laki & 66 & 95,65 \\
\hline Perempuan & 3 & 4,35 \\
\hline Jumlah & 69 & 100,00 \\
\hline Sumber: Data penelitian, 2019 &
\end{tabular}

Dari tabel di atas diketahui 29 orang atau $96,1 \%$ sampel dalam penelitian ini adalah laki-laki dan 2 orang atau 3,9\% dalam penelitian ini adalah perempuan. Pemilihan responden lebih banyak berjenis kelamin laki-laki karena Tentara Nasional Indonesia di Komando Distrik Militer lebih banyak laki-laki dibandingkan dengan perempuan, sehingga $96,1 \%$ responden adalah laki-laki.

Tabel 2. Karakteristik Responden Berdasarkan Pendidikan

\begin{tabular}{lll}
\hline $\begin{array}{l}\text { Tingkat } \\
\text { Pendidikan }\end{array}$ & $\begin{array}{l}\text { Frekuensi } \\
\text { (Orang) }\end{array}$ & $\begin{array}{l}\text { Persentase } \\
(\%)\end{array}$ \\
\hline SMP & 6 & 8,70 \\
\hline SMA & 60 & 86,96 \\
\hline S1 & 2 & 4,35 \\
\hline Jumlah & 69 & 100,00 \\
\hline
\end{tabular}

Sumber: Data Penelitian, 2019

Dilihat pada tabel di atas diketahui bahwa tingkat pendidikan Tentara Nasional Indonesia di Komando Distrik Militer 0618/BS yang paling banyak adalah SMA yaitu sebanyak 44 orang dengan persentasi $86,3 \%$ dan untuk kedua terbanyak yaitu SMP dengan jumlah 5 orang dengan persentasi $9,8 \%$ dan yang terakhir adalah S1 atau Sarjana dengan jumlah 2 orang atau 3,9\%. Dari tabel tersebut dapat dilihat ternyata tingkat pendidikan TNI di Komando Distrik Militer 0618/BS masih tergolong rendah, hal tersebut disebabkan karena persyaratan saat masuk TNI adalah minimal SMA/SMP (sesuai jabatan) sehingga TNI di Komando Distrik Militer 0618 rata-rata pendidikan terakhirnya adalah SMA.

Tabel 3. Karakteristik Responden Berdasarkan Masa Kerja

\begin{tabular}{lll}
\hline $\begin{array}{l}\text { Masa Kerja } \\
\text { (Tahun) }\end{array}$ & $\begin{array}{l}\text { Frekuensi } \\
\text { (Orang) }\end{array}$ & $\begin{array}{l}\text { Persentasi } \\
(\%)\end{array}$ \\
\hline $6-10$ & 6 & 8,70 \\
\hline $11-15$ & 15 & 21,74 \\
\hline $16-20$ & 27 & 39,13 \\
\hline $21-25$ & 8 & 11,59 \\
\hline $26-30$ & 5 & 7,25 \\
\hline $30<$ & 8 & 11,59 \\
\hline Jumlah & 69 & 100,00 \\
\hline Sumber: Data Penelitian, 2019 &
\end{tabular}

Dilihat dari data diatas ternyata masa kerja TNI di sana yang terbanyak adalah dari 16-20 tahun yaitu sebanyak 27 orang dengan presentasi 39,13\%.

Tabel 4. Karakteristik Berdasarkan Pangkat

\begin{tabular}{lll}
\hline Pangkat & $\begin{array}{l}\text { Frekuensi } \\
\text { (Orang) }\end{array}$ & $\begin{array}{l}\text { Persentase } \\
\text { (\%) }\end{array}$ \\
\hline Tamtama & 7 & 10,14 \\
\hline Bintara & 54 & 78,26 \\
\hline Perwira & 8 & 11,59 \\
\hline Jumlah & 69 & 100,00 \\
\hline
\end{tabular}

Sumber: Data Penelitian, 2019

Tabel di atas sesuai dengan tingkat pendidikannya bahwa mayoritas responden yaitu Bintara sesuai dengan salah satu syarat menjadi bintara adalah lulusan SMA. Hal tersebut terlihat bahwa yang memiliki pangkat Bintara adalah 39 orang atau $76,5 \%$ sedangkan yang memiliki pangkat perwira sebanyak 7 orang atau sebanyak $13,7 \%$ dan yang terakhir yaitu tamtama yaitu hanya 5 orang saja yang memiliki presentasi yaitu 9,80\%.

\section{Persepsi Responden terhadap Faktor- faktor yang Mempengaruhi Kinerja TNI}

Dari hasil kuisioner yang disebarkan kepada 69 orang TNI di Komando Distrik Militer 0618/BS Kota Bandung sebagai 
sample dalam penelitian ini, diketahui persepsi responden terhadap faktor-faktor yang mempengaruhi kinerja pegawai sebagai berikut:

\section{a. Persepsi Responden terhadap Personal Factors}

Dari hasil kuisoner yang berhubungan dengan personal factor, yaitu faktor dari dalam diri TNI itu sendiri yang ditunjukan oleh komitmen, keterampilan, motivasi serta komitmen yang dapat mempengaruhi kinerja TNI itu sendiri. Berikut ini adalah persepsi TNI tentang personal factor seperti pada Tabel 5 .

Tabel 5. Persepsi Responden terhadap Personal Factor

\begin{tabular}{|c|c|c|c|c|c|c|c|c|}
\hline \multirow[t]{2}{*}{ No. } & \multirow[t]{2}{*}{ Pertanyaan } & \multicolumn{5}{|c|}{ Tanggapan Responden } & \multirow[t]{2}{*}{ Jlh } & \multirow[t]{2}{*}{ Kriteria } \\
\hline & & SS & $\mathrm{S}$ & CS & TS & STS & & \\
\hline$\overline{1}$ & $\begin{array}{l}\text { TNI adalah } \\
\text { profesi } \\
\text { yang dicita- } \\
\text { citakan }\end{array}$ & 50 & 14 & 0 & 2 & 3 & 313 & $\begin{array}{l}\text { Sangat } \\
\text { baik }\end{array}$ \\
\hline 2 & $\begin{array}{l}\text { Pekerjaan } \\
\text { orang tua/ } \\
\text { keluarga } \\
\text { adalah TNI }\end{array}$ & 24 & 14 & 10 & 9 & 12 & 236 & Baik \\
\hline 3 & $\begin{array}{l}\text { Tugas } \\
\text { dilaksana- } \\
\text { kan dengan } \\
\text { lancar }\end{array}$ & 49 & 5 & 10 & 5 & 0 & 305 & $\begin{array}{l}\text { Sangat } \\
\text { Baik }\end{array}$ \\
\hline 4 & $\begin{array}{l}\text { Kepuasan } \\
\text { bekerja } \\
\text { sebagai TNI }\end{array}$ & 50 & 9 & 5 & 2 & 3 & 308 & $\begin{array}{l}\text { Sangat } \\
\text { Baik }\end{array}$ \\
\hline 5 & $\begin{array}{l}\text { Kesesuaian } \\
\text { pekerjaan } \\
\text { dengan } \\
\text { bidang/ } \\
\text { keahlian }\end{array}$ & 43 & 16 & 5 & 0 & 5 & 299 & $\begin{array}{l}\text { Sangat } \\
\text { Baik }\end{array}$ \\
\hline
\end{tabular}

Tabel 6. Kriteria Penilaian

Kuesioner Personal Factor

\begin{tabular}{ll}
\hline Kategori & Rentang \\
\hline Sangat Baik & $290-345$ \\
\hline Baik & $234-289$ \\
\hline Cukup Baik & $176-233$ \\
\hline Tidak Baik & $124-175$ \\
\hline Sangat Tidak Baik & $69-123$ \\
\hline \multicolumn{2}{l}{ Sumber: Data penelitian, 2019 }
\end{tabular}

Dilihat dari hasil penilaian personal factor, terlihat bahwa dari 5 pertanyaan yang diajukan diperoleh jawaban yang mengarahkan bahwa tingkat kemandirian, latar belakang keluarga, bekerja sesuai dengan bidang yang mereka kuasai, sehingga dapat menyelesaikan tugas tepat waktu, masuk ke dalam kategori sangat baik dan baik.

Dapat terlihat dari Tabel 5 bahwa persepsi responden untuk pertanyaan mengenai personal factor rata-rata memiliki jumlah nilai 292 yang masuk dalam kriteria sangat baik. Pada Tabel 5 terlihat jelas komitmen individu sangat kuat, hal tersebut dibuktikan dari pertanyaan mengenai TNI adalah profesi yang bapak atau ibu cita-citakan memiliki kriteria sangat baik dengan nilai 313 hal itu menandakan bahwa profesi sebagai TNI adalah impian sebagian besar TNI di Kodim 0618/BS Kota Bandung sehingga mereka memiliki komitmen yang tinggi dan berpengaruh terhadap kinerja TNI di Kodim 0618/BS Kota Bandung. Menurut Spencer dan Spencer (Sudarmanto, 2009: 102), komitmen individu yang kuat terhadap organisasi akan memudahkan pimpinan untuk menggerakkan sumber daya manusia dalam mencapai tujuan organisasi.

Selain itu, latar belakang juga mempengaruhi komitmen yang kuat pada diri TNI dikarenakan lingkungan keluarga merupakan kelompok sosial pertama-tama dalam kehidupan manusia tempat ia belajar dan menyatakan diri sebagai manusia sosial di dalam hubungan interaksi dengan kelompoknya. Dalam keluarganya, yang interaksi sosial keluarganya berdasarkan simpati, seorang anak pertama-tama belajar memperhatikan keinginan-keinginan orang lain, belajar bekerja sama, bantu membantu, dengan kata lain, anak pertama-tama belajar memegang perananan sebagai makhluk sosial yang mempunyai normanorma dan kecakapan-kecakapan tertentu dalam pergaulannya dengan orang lain (Purwodarminto, 2011: 43)

Pengertian lingkungan keluarga berasal dari dua kata, yaitu lingkungan dan keluarga. J. P. Chaplin (Syamsu Yusuf, 2000) mengemukakan bahwa "lingkungan merupakan keseluruhan aspek atau fenomena fisik atau sosial yang mempengaruhi perkembangan individu. Sementara, Joe Kathena (Syamsu Yusuf, 2000) mengemu- 
kakan bahwa "lingkungan merupakan segala sesuatu yang berada di luar individu yang meliputi fisik dan sosial budaya". Lingkungan ini merupakan susmber seluruh informasi yang diterima individu melalui alat inderanya yaitu penglihatan, penciuman, pendengaran, dan rasa.

Sehingga secara tidak langsung membuat TNI di Komando Distrik Militer 0618/BS memiliki komitmen yang tinggi terhadap pekerjaannya dikarenakan latar belakang mereka yang sebagian besar adalah keluarga TNI yang didalamnya sudah ada nilai-nilai atau aspek-aspek tertentu terhadap TNI itu sendiri.

Pekerjaan dapat dilaksanakan dengan baik dan lancar dikarenakan adanya komitmen yang kuat sehingga mereka bisa bekerja dengan segala tantangan yang ada terlebih lagi menurut mereka, dari hasil wawancara yang dilakukan bahwa mereka telah melakukan beberapa pelatihanpelatihan khusus yang menambah skill yang mereka miliki. Sehingga hal-hal tersebut mendukung terciptanya kinerja yang baik khususnya dalam dimensi personal factor.

Dengan dimensi personal factor dalam kategori sangat baik tersebut, dapat dimaknai bahwa secara umum Tentara Negara Indonesia (TNI) di Komando Distrik Militer (KODIM) 0618/BS memiliki tingkat kemandirian untuk menyesesaikan pekerjaan, adanya keinginan yang tinggi untuk bekerja sebagai TNI, serta bekerja sesuai dengan bidangnya.

Dilihat dari sisi kemandirian dapat dikatakan bahwa setiap TNI di Kodim 0618/BS sudah mengetahui tugas pokok dan fungsi masing-masing individu sehingga target-target pekerjaan dapat terlaksana dengan baik dan sesuai dengan waktu yang talah ditentukan. Selain itu dilihat dari masa kerja TNI di Kodim 0618/BS Kota Bandung ternyata sebanyak $60 \%$ sudah memiliki masa kerja diatas 15 tahun, sehingga hal tersebut pula yang mendukung mengapa personal dari TNI di Kodim 0618/BS Kota Bandung sudah dapat bekerja secara mandiri. Raharjo (1999) mengatakan bahwa kualitas sumber daya manusia tidak hanya ditentukan oleh aspek ketrampilan atau kekuatan tenaga fisiknya saja akan tetapi ditentukan juga oleh pengalaman atau kematangannya dalam melakukan pekerjaan.

Kreitner dan Kinicki (2004) mengatakan apabila seseorang telah melewati masa kerja yang lama akan lebih membuat seorang pegawai lebih merasa betah dalam suatu organisasi, hal ini dikarenakan di antaranya karena telah beradaptasi dengan lingkungannya yang cukup lama sehingga seorang pegawai akan merasa lebih nyaman dengan pekerjaannya.

Menurut hasil wawancara yang peneliti lakukan, beberapa di antara mereka memiliki Ayah, Kakek ataupun Kakak seorang TNI sehingga ada panutan yang menjadikan mereka menginginkan sebagai TNI. Adanya pola pikir apabila mereka bekerja sebagai TNI akan membuat keadaan financial mereka aman sampai mereka tua sehingga hal tersebut memotivasi mereka untuk bekerja sebagai TNI. Kegiatankegiatan yang mereka lakukan biasanya rutin dilakukan setiap tahunnya sehingga membuat mereka terbiasa melakukannya dan dapat menyelesaikan segala tugastugasnya tepat waktu. Displin adalah sesuatu yang wajib mereka tanamkan pada diri TNI sehingga apapun tugas harus dilakukan tepat waktu dan selesai sesuai waktu yang telah mereka tentukan.

Dilihat dari keahliannya para TNI di Kodim sudah bekerja sesuai dengan tingkat keahlian yang mereka miliki, hal itu dikarenakan adanya pelatihan-pelahitan tambahan untuk menunjang pekerjaan yang mereka kerjakan.

\section{b. Persepsi Responden terhadap Leadership Factors}

Dari hasil kuisoner yang berhubungan dengan leadership factor, yaitu bagaimana seorang pemimpin membimbing, memberi- 
kan arahan, dorongan, memberikan penghargaan terhadap pegawai yang berprestasi, dan hal-hal yang dapat mempengaruhi kinerja TNI itu sendiri. Berikut ini adalah persepsi TNI tentang leadership factor seperti ditunjukkan pada Tabel 7.

Tabel 7. Persepsi Responden terhadap Leadership Factor

\begin{tabular}{lllllllll}
\hline No. & Pertanyaan & \multicolumn{3}{c}{ Tanggapan Responden } & Jlh & Kriteria \\
\cline { 2 - 5 } & SS & S & CS & TS & STS & & \\
\hline 1 & $\begin{array}{l}\text { Pimpinan selalu memberi- } \\
\text { kan bimbingan arahan dan } \\
\text { dorongan kepada bawahan }\end{array}$ & 23 & 10 & 0 & 3 & 290 & $\begin{array}{l}\text { Sangat } \\
\text { baik }\end{array}$ \\
\hline 2 & $\begin{array}{l}\text { Pimpinan mampu men- } \\
\text { ciptakan suasana kerja } \\
\text { yang kondusif }\end{array}$ & 28 & 11 & 3 & 0 & 286 & Baik \\
\hline 3 & $\begin{array}{l}\text { Pimpinan memberikan } \\
\text { penghargaan kepada pega- } \\
\text { wai }\end{array}$ & 25 & 16 & 3 & 0 & 305 & $\begin{array}{l}\text { Sangat } \\
\text { Baik }\end{array}$ \\
\hline 4 & $\begin{array}{l}\text { Pimpinan ikut andil sangat } \\
\text { besar dalam melaksanakan }\end{array}$ & 24 & 8 & 3 & 0 & 296 & $\begin{array}{l}\text { Sangat } \\
\text { Baik }\end{array}$ \\
\hline 5 & $\begin{array}{l}\text { Dukungan pimpinan akan } \\
\text { mempengaruhi kinerja }\end{array}$ & 16 & 7 & 1 & 3 & 300 & $\begin{array}{l}\text { Sangat } \\
\text { Baik }\end{array}$ \\
\hline 6 & $\begin{array}{l}\text { Pimpinan bapak/ Ibu saat } 17 \\
\text { ini adalah pemimpin yang } \\
\text { ideal }\end{array}$ & & 15 & 7 & 0 & 264 & Baik \\
\hline Sumber: Data Penelitian, 2019 & & & & & & & \\
\hline
\end{tabular}

Tabel 8. Kriteria Penilaian Kuesioner Leadership

\begin{tabular}{ll}
\hline Kategori & Rentang \\
\hline Sangat Baik & $290-345$ \\
\hline Baik & $234-289$ \\
\hline Cukup Baik & $176-233$ \\
\hline Tidak Baik & $124-175$ \\
\hline Sangat Tidak Baik & $69-123$ \\
\hline
\end{tabular}

Sumber: Data Penelitian, 2019

Dapat dilihat dari Tabel 7 bahwa faktor pemimpin dalam kinerja TNI di Komando Distrik Militer sangat baik, hal tersebut mencerminkan bahwa pemimpin di Kodim dapat memberikan bimbingan, arahan serta dorongan kepada para bawahan agar bekerja lebih baik dan sesuai dengan tujuan yang dituju bersama, pimpinan pun dapat menciptakan suasana kerja yang kondusif sehingga para staff dapat bekerja secara maksimal. Hal tersebut dapat disimpulkan bahwa pimpinan di KODIM 0618/BS Kota Bandung dapat membuat iklim kerja yang posittif seperti yang dikatakan Miller (1997: 128) bahwa iklim kerja adalah nilai semangat yang mendasar dalam cara mengelola hubungan dan mengorganisasikannya. Nilai-nilai itu berbentuk prinsip dan keyakinan yang bisa tersurat, namun juga ada yang hanya tersirat. Nilai-nilai ini akan mempengaruhi individu dalam melakukan tugas-tugas dalam organisasi.

Menurut Davis dan Newstrom, (2001: 25), iklim kerja sebagai kepribadian sebuah organisasi yang membedakan dengan organisasi lainnya yang mengarah pada persepsi masing-masing anggota dalam memandang organisasi. Semua organisasi memiliki iklim kerja yang manusiawi dan partisipasif, sesuai dengan gaya kepemimpinan. Dengan demikian dapat dikatakan bahwa iklim organisasi dimaksudkan untuk memberikan lingkungan pengasuhan yang mengakui bahwa pegawai diperlakukan sebagai individu. Dengan demikian, iklim kerja merupakan alat untuk memecahkan masalah (solusi) yang secara konsisten dapat berjalan dengan baik bagi suatu kelompok atau lembaga tertentu dalam menghadapi persoalan eksternal dan internalnya. Hal ini dapat ditularkan atau diajarkan kepada para indivivu untuk berpendapat, dan merasakan dalam hubungannya dengan persoalan-persoalan tersebut. Selain itu pimpinan memberikan penghargaan kepada staff yang berprestasi baik itu dengan ucapan atau reward tertentu.

Di samping itu, pimpinan ikut andil sangat besar dalam melaksanakan berbagai tugas sehingga staff sangat terbantu serta makin terarah untuk mencapai tujuan. TNI adalah salah satu penganut sistem komando yang artinya apapun perintah atasan wajib hukumnya untuk dilaksanakan sehingga dapat terlihat bahwa dampak atau efek dari faktor pemimpin itu sangat tinggi.

\section{c. Persepsi Responden terhadap Team Factor}

Dari hasil kuisoner yang berhubungan dengan team factor, yaitu bagaimana dukungan terhadap rekan kerja, team kerja bekerja dengan baik sehingga dapat mempengaruhi kinerja TNI itu sendiri. Berikut ini adalah persepsi TNI tentang team factor seperti pada Tabel 9. 
Tabel 9. Persepsi Responden terhadap Team Factor

\begin{tabular}{|c|c|c|c|c|c|c|c|c|}
\hline \multirow[t]{2}{*}{ No } & \multirow[t]{2}{*}{ Pertanyaan } & \multicolumn{5}{|c|}{ Tanggapan Responden } & \multirow[t]{2}{*}{ Jlh } & \multirow[t]{2}{*}{ Kriteria } \\
\hline & & SS & $\mathrm{s}$ & CS & TS & STS & & \\
\hline 1 & $\begin{array}{l}\text { Saat ini kinerja } \\
\text { dipengaruhi oleh } \\
\text { rekan kerja }\end{array}$ & 46 & 20 & 0 & 0 & 3 & 313 & $\begin{array}{l}\text { Sangat } \\
\text { baik }\end{array}$ \\
\hline 2 & 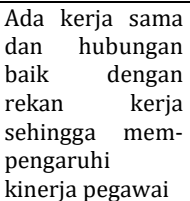 & 53 & 13 & 0 & 0 & 3 & 320 & $\begin{array}{l}\text { Sangat } \\
\text { Baik }\end{array}$ \\
\hline 3 & $\begin{array}{l}\text { Tugas dan fungsi } \\
\text { dilaksanakan } \\
\text { dengan baik, jika } \\
\text { mendapatkan } \\
\text { dukungan dari } \\
\text { rekan kerja }\end{array}$ & 52 & 14 & 0 & 3 & 0 & 322 & $\begin{array}{l}\text { Sangat } \\
\text { Baik }\end{array}$ \\
\hline 4 & $\begin{array}{l}\text { Saran dan petun- } \\
\text { juk pelaksanaan } \\
\text { tugas yang baik } \\
\text { dari rekan kerja } \\
\text { menghasilkan } \\
\text { kinerja yang baik }\end{array}$ & 50 & 16 & 0 & 0 & 3 & 317 & $\begin{array}{l}\text { Sangat } \\
\text { Baik }\end{array}$ \\
\hline 5 & $\begin{array}{lr}\text { Rekan } & \text { kerja } \\
\text { sudah } & \text { bekerja } \\
\text { sesuai peran dan } \\
\text { tugas masing- } \\
\text { masing }\end{array}$ & 50 & 15 & 1 & 3 & 0 & 319 & $\begin{array}{l}\text { Sangat } \\
\text { Baik }\end{array}$ \\
\hline
\end{tabular}

Sumber: Data Penelitian, 2019

Tabel 10. Kriteria Penilaian Kuesioner Team Factor

\begin{tabular}{ll}
\hline Kategori & Rentang \\
\hline Sangat Baik & $290-345$ \\
\hline Baik & $234-289$ \\
\hline Cukup Baik & $176-233$ \\
\hline Tidak Baik & $124-175$ \\
\hline Sangat Tidak Baik & $69-123$ \\
\hline
\end{tabular}

Sumber: Data Penelitian, 2019

Melihat Tabel 9 di atas bisa dikatakan bahwa team factor TNI di Komando Distrik Militer 0618/BS Kota Bandung dikatakan sangat baik melihat kriteria yang telah ditentukan. Melihat dari beberapa pertanyaan diatas dapat disimpulkan bahwa lingkungan kerja non fisik. Lingkungan kerja non fisik sangat mempengaruhi kepuasan kerja karyawan, dimana jika keadaan atau situasi di sekitar karyawan kondusif untuk bekerja, rekan mudah diajak untuk bekerja sama dan hubungan dengan atasan baik maka karyawan akan menikmati pekerjaannya dan merasa puas bekerja di tempat tersebut, hal tersebut disebutkan oleh Wusanto (2009: 269). TNI di Komando Distrik Militer 0618/BS memiliki team factor sangat baik, yang didalamnya terdapat tim-tim kerja yang cukup solid, hal ini dikarenakan bahwa hubungan erat antar TNI satu dengan lainnya sudah dipupuk sejak mereka masih di Akademi Militer.

Menurut hasil wawacara yang telah penulis lakukan, mereka sudah mengenal satu sama lain selama di akademi walaupun tidak selalu satu angkatan, sehingga timbulah rasa persaudaraan antar relasi. Banyaknya kegiatan yang dilakukan bersama-sama juga membuat semakin eratnya hubungan antar TNI di kodim. Hal tersebut dijelaskan oleh salah satu narasumber kita, menurutnya setiap kegiatan entah di kantor ataupun di luar kantor yang turun langsung ke lapangan mengharuskannya untuk kompak satu sama lain, apabila mengerjakan tidak kompak pasti akan terjadi salah paham yang akan berakibat tidak baik dalam pekerjaan dan malah kita kerja dua kali.

Team factor TNI di Komando Distrik Militer 0618/BS Kota Bandungsudah sangat baik dikarenakan sudah timbulnya rasa persaudaraan antar TNI sejak masa pendidikan lalu ditambah lagi kegiatan-kegiatan di Kodim 0618/BS Kota Bandung yang mengaharuskan mereka bekerja secara kompak sehingga tertanamlah rasa persaudaraan satu sama lain. Hal tersebut membuat lingkungan kerja non fisik di Kodim 0618/BS Kota Bandung sudah sangat baik dan dapat mendukung kinerja di TNI di Kodim 0618/BS Kota Bandung.

Leblebici (2012) mengatakan dimana lingkungan kerja non fisik memiliki pengaruh yang besar terhadap kepuasan kerja. Hal tersebut menunjukan kepuasan kerja dapat ditingkatkan melalui lingkungan kerja non fisik. Dikarenakn tingkat kepuasan kerja tinggi maka tinggi pula kinerjanya.

\section{d. Persepsi Responden terhadap System Factor}

Dari hasil kuisoner yang berhubungan dengan system factor, yaitu bagaimana sistem kerja, fasilitas dapat mempengaruhi kinerja TNI itu sendiri. Berikut ini adalah 
persepsi TNI tentang system factor seperti ditunjukkan pada Tabel 11.

Tabel 11. Persepsi Responden terhadap System Factor

\begin{tabular}{|c|c|c|c|c|c|c|c|c|}
\hline \multirow[t]{2}{*}{ No } & \multirow[t]{2}{*}{ Pertanyaan } & \multicolumn{5}{|c|}{ Tanggapan Responden } & \multirow[t]{2}{*}{ Jlh } & \multirow[t]{2}{*}{ Kriteria } \\
\hline & & SS & $\mathrm{S}$ & $\mathrm{CS}$ & TS & STS & & \\
\hline 1 & $\begin{array}{l}\text { Kinerja setiap pegawai } \\
\text { tidak terlepas dari sistem } \\
\text { dalam organisasi }\end{array}$ & 48 & 18 & 0 & 3 & 0 & 318 & $\begin{array}{l}\text { Sangat } \\
\text { baik }\end{array}$ \\
\hline 2 & $\begin{array}{l}\text { Kinerja pegawai dipenga- } \\
\text { ruhi oleh fasilitas dalam } \\
\text { organisasi }\end{array}$ & 52 & 14 & 0 & 0 & 3 & 319 & $\begin{array}{l}\text { Sangat } \\
\text { Baik }\end{array}$ \\
\hline 3 & $\begin{array}{l}\text { Sistem karir yang baik } \\
\text { memberikan } \\
\text { pegawai motivasi } \\
\text { kinerjanya }\end{array}$ & 50 & 16 & 0 & 0 & 3 & 317 & $\begin{array}{l}\text { Sangat } \\
\text { Baik }\end{array}$ \\
\hline 4 & $\begin{array}{l}\text { Sistem komando saat ini } \\
\text { sangat efektif dalam } \\
\text { meningkatkan kinerja }\end{array}$ & 41 & 24 & 1 & 3 & 0 & 310 & $\begin{array}{l}\text { Sangat } \\
\text { Baik }\end{array}$ \\
\hline 5 & $\begin{array}{l}\text { Dukungan teknologi infor- } \\
\text { masi yang memadai } \\
\text { mendukung pelaksanaan } \\
\text { tugas dan fungsi yang } \\
\text { cepat dan tepat }\end{array}$ & 46 & 20 & 0 & 0 & 3 & 313 & $\begin{array}{l}\text { Sangat } \\
\text { Baik }\end{array}$ \\
\hline
\end{tabular}

Tabel 12. Kriteria Penilaian Kuesioner System Factor

\begin{tabular}{ll}
\hline Kategori & Rentang \\
\hline Sangat Baik & $290-345$ \\
\hline Baik & $234-289$ \\
\hline Cukup Baik & $176-233$ \\
\hline Tidak Baik & $124-175$ \\
\hline Sangat Tidak Baik & $69-123$ \\
\hline Sumber: Data Penelitian, 2019
\end{tabular}

Melihat Tabel 11 di atas bisa dikatakan bahwa system factor TNI di Komando Distrik Militer 0618/BS Kota Bandung dikatakan sangat baik melihat kriteria yang telah ditentukan. Melihat dari pertanyaan yang mengacu pada fasilitas dapat dikatakan bahwa fasilitas salah satu aspek dari system factor yang mendukung kinerja TNI di Kodim 0618/BS Kota Bandung. Fasilitas adalah aspek dari lingku-ngan kerja fisik. Lingkungan kerja fisik menurut Nitisemito (Nuraini 2013: 97) linkungan kerja fisik adalah segala sesuatu yang ada disekitar karyawan dan dapat mempengaruhi dalam menjalankan tugas yang diembankan kepadanya misalnya dengan adanya air conditioner $(A C)$, penerangan yang memadai dan sebagainya.

Sehingga dapat dikatakan bahwa system factor di Kodim 0618/BS Kota Bandung dikatakan sangat baik disebabkan salah satunya memiliki fasilitas yang sangat baik guna mendukung kinerja TNI di Kodim 0618/BS Kota Bandung, sesuai dengan wawancara yang telah penulis lakukan bahwa ternyata TNI di Kodim memiliki ruangan yang cukup luas sehingga cukup nyaman melakukan pekerajaan di dalam ruangan, sedangkan apabila melakukan dinas luar TNI di Kodim 0618/BS Kota Bandung difasilitasi kendaraan dinas baik mobil ataupun motor yang sudah disediakan oleh Kantor Kodim 0618/BS itu sendiri sehingga hal tersebut pasti akan mendukung kinerja dari TNI di Kodim 0618/BS Kota Bandung itu sendiri.

Sistem komando adalah salah satu nilai yang harus tertanam kuat pada diri TNI itu sendiri karena untuk mejaga keamanan negara dibutuhkan 1 komando demi terciptanya keselarasan diseluruh TNI di Indonesia. Hal tersebut tentu dapat meningkatkan kinerja dari TNI itu sendiri khususnya di Kodim 0618/BS dikarenakan adanya rasa patuh terhadap atasan sehingga mau tidak amu, suka tidak suka mereka harus menjalankan perintah atasan secara langsung dan tepat waktu.

Menurut hasil wawancara, TNI di Kodim 0618/BS sudah terbiasa dan sudah merasa perintah atasan adalah suatu kewajiban yang mereka penuhi suka atau tidak, dalam keadaan dinas ataupun sedang tidak dinas, itu adalah komitmen yang sudah mereka pegang sejak masuk sebagai TNI sehingga kinerja TNI di Kodim 0618/BS Kota Bandung bisa baik sampai dengan saat ini.

\section{e. Persepsi Responden terhadap Contextual Factor}

Dari hasil kuisioner yang berhubungan dengan contextual factor, yaitu bagaimana tekanan pimpinan, dukungan internal maupun eksternal, suasana organisasi dan lain-lain, sehingga dapat mempengaruhi kinerja TNI itu sendiri. Berikut ini adalah persepsi TNI tentang contextual factor seperti ditunjukkan pada Tabel 13. 
Tabel 13. Persepsi Responden terhadap Contextual factor

\begin{tabular}{|c|c|c|c|c|c|c|c|c|}
\hline \multirow[t]{2}{*}{ No } & \multirow[t]{2}{*}{ Pertanyaan } & \multicolumn{5}{|c|}{$\begin{array}{l}\text { Tanggapan } \\
\text { Responden }\end{array}$} & \multirow[t]{2}{*}{ Jlh } & \multirow[t]{2}{*}{ Kriteria } \\
\hline & & SS & $\mathrm{S}$ & $\mathrm{CS}$ & TS & STS & & \\
\hline 1 & $\begin{array}{l}\text { Tekanan dari pimpinan } \\
\text { akan membuat pegawai } \\
\text { menjadi stress dan mem- } \\
\text { pengaruhi kinerja }\end{array}$ & 48 & 12 & 6 & 3 & 0 & 312 & $\begin{array}{l}\text { Sangat } \\
\text { baik }\end{array}$ \\
\hline 2 & $\begin{array}{l}\text { Suasana organisasi yang } \\
\text { tidak nyaman membuat } \\
\text { pegawai menjadi malas } \\
\text { yang akan mempengaruhi } \\
\text { pada kinerja pegawai }\end{array}$ & 50 & 14 & 2 & 3 & 0 & 318 & $\begin{array}{l}\text { Sangat } \\
\text { Baik }\end{array}$ \\
\hline 3 & $\begin{array}{l}\text { Dukungan dari lingkungan } \\
\text { eksternal, khususnya ling- } \\
\text { kungan terdekat dengan } \\
\text { instansi akan mempe- } \\
\text { ngaruhi kinerja pegawai }\end{array}$ & 45 & 19 & 2 & 3 & 0 & 313 & $\begin{array}{l}\text { Sangat } \\
\text { Baik }\end{array}$ \\
\hline 4 & $\begin{array}{l}\text { Perubahan lingkungan } \\
\text { organisasi juga mempe- } \\
\text { ngaruhi kinerja pegawai }\end{array}$ & 48 & 16 & 2 & 3 & 0 & 316 & $\begin{array}{l}\text { Sangat } \\
\text { Baik }\end{array}$ \\
\hline 5 & $\begin{array}{l}\text { Adanya ancaman internal } \\
\text { maupun eksternal sehing- } \\
\text { ga mau tidak mau anda } \\
\text { bekerja dengan maksimal }\end{array}$ & 44 & 13 & 6 & 5 & 1 & 301 & $\begin{array}{l}\text { Sangat } \\
\text { Baik }\end{array}$ \\
\hline
\end{tabular}

Tabel 14. Kriteria Penilaian Kuesioner Contextual Factor

\begin{tabular}{ll}
\hline Kategori & Rentang \\
\hline Sangat Baik & $290-345$ \\
\hline Baik & $234-289$ \\
\hline Cukup Baik & $176-233$ \\
\hline Tidak Baik & $124-175$ \\
\hline Sangat Tidak Baik & $69-123$ \\
\hline
\end{tabular}

Sumber: Data Penelitian, 2019

Melihat Tabel 13 di atas bahwa ternyata contextual factor yang ada di Kodim 0618/BS Kota Bandung sangat baik berdasarkan kriteria yang telah ditentukan. Ini berarti bahwa pengaruh luar atau contextual factor memengaruhi terhadap kinerja di Kodim 0618/BS Kota Bandung. Contextual/situational factors (faktor konteks/situasi) ditunjukkan oleh tingginya tingkat tekanan dan perubahan lingkungan internal dan eksternal. Nitisemito (Nitisemito, 1992: 25) mendefinisikan bahwa "lingkungan kerja adalah sesuatu yang ada di sekitar para pekerja dan yang mempengaruhi dirinya dalam menjalankan tugas-tugas yang dibebankan". Selanjutnya menurut Sedarmayati (2001: 1) "lingkungan kerja merupakan keseluruhan alat perkakas dan bahan yang dihadapi, lingkungan sekitarnya dimana seseorang bekerja, metode kerjanya, serta pengaturan kerjanya baik sebagai perseorangan maupun sebagai kelompok". Kondisi lingkungan kerja dikatakan baik atau sesuai apabila manusia dapat melaksanakan kegiatan secara optimal, sehat, aman, dan nyaman. Kesesuaian lingkungan kerja dapat dilihat akibatnya dalam jangka waktu yang lama lebih jauh lagi lingkungan-lingkungan kerja yang kurang baik dapat menuntut tenaga kerja dan waktu yang lebih banyak dan tidak mendukung diperolehnya rancangan sistem kerja yang efisien (Sedarmayanti, 2001: 12).

Menurut Bambang Kusriyanto (1991: 122), lingkungan kerja merupakan salah satu faktor yang mempengaruhi kinerja seorang pegawai. Seorang pegawai yang bekerja di lingkungan kerja yang mendukung dia untuk bekerja secara optimal akan menghasilkan kinerja yang baik, sebaliknya jika seorang pegawai bekerja dalam lingkungan kerja yang tidak memadai dan tidak mendukung untuk bekerja secara optimal akan membuat pegawai yang bersangkutan menjadi malas, cepat lelah sehingga kinerja pegawai tersebut akan rendah. Dari beberapa pendapat di atas dapat disimpulkan bahwa lingkungan kerja merupakan segala sesuatu yang ada di sekitar pegawai pada saat bekerja, baik berbentuk fisik atau non fisik, langsung atau tidak langsung, yang dapat mempengaruhi dirinya dan pekerjaannya saat bekerja.

Sedarmayanti (2001: 21) secara garis besar membagi lingkungan kerja menjadi dua yakni: (a) Lingkungan Kerja Fisik. Lingkungan kerja fisik adalah semua keadaan berbentuk fisik yang terdapat di sekitar tempat kerja yang dapat mempengaruhi pegawai baik secara langsung maupun tidak langsung. Lingkungan kerja fisik dapat dibagi menjadi dua kategori yaitu: (1) Lingkungan kerja yang langsung berhubungan dengan pegawai seperti; pusat kerja, kursi, meja, dan sebagainya; dan (2) lingkungan perantara atau lingkungan umum dapat juga disebut lingkungan kerja yang mempengaruhi 
kondisi manusia misalnya temperatur, kelembaban, sirkulasi udara, pencahayaan, kebisingan, getaran mekanik, bau tidak sedap, warna dan lain-lain. (b) Lingkungan Kerja Non Fisik. Lingkungan kerja non fisik adalah semua keadaan yang terjadi yang berkaitan dengan hubungan kerja, baik hubungan dengan atasan, maupun hubungan dengan sesama rekan kerja ataupun hubungan dengan bawahan. Lingkungan kerja bermanfaat dan berhubungan dengan kinerja karyawan. Ishak dan Tanjung (2003) menjelaskan bahwa manfaat lingkungan kerja adalah menciptakan gairah kerja, sehingga produktivitas dan prestasi kerja meningkat.

Sementara itu, manfaat yang diperoleh karena bekerja dengan orang-orang yang termotivasi adalah pekerjaan dapat terselesaikan dengan tepat, yang artinya pekerjaan diselesaikan sesuai standar yang benar dan dalam skala waktu yang ditentukan. Prestasi kerjanya akan dipantau oleh individu yang bersangkutan, dan tidak akan menimbulkan terlalu banyak pengawasan serta semangat juangnya akan tinggi. Merangkum berbagai pendapat di atas tentang faktor situasional yang berhubungan dengan lingkungan kerja, maka bisa disimpulkan bahwa lingkungan kerja erat kaitannya dengan kinerja pegawai. Hal tersebut menyimpulkan bahwasannya lingkungan kerja TNI di Kodim 0618/BS Kota Bndung sangat mendukung kinerja TNI di Kodim 0618/BS itu sendiri sehingga kinerja TNI Kodim 0618/BS Kota Bandung dapat dikatakan baik pula. Dilihat dari hasil angket terhadap responden maka penulis melakukan PLS (Partial Least Square) yang pada akhirnya akan menghasilkan faktor-faktor apa saja yang berpengaruh terhadap kinerja terlebih lagi sample yang digunakan hanya 69 sample sehingga sangat cocok menggunakan motode PLS (Partial Least Square).

\section{Evaluasi Pengukuran Model}

Evaluasi terhadap model pengukuran indikator meliputi pemerikasaan individual item reliability, internal consistency atau composite reliability, average variance extracted, dan discriminant validity. Ketiga pengukuran pertama dikelompokkan dalam convergent validity.

\section{Convergent Validity}

Convergent validity terdiri dari tiga pengujian yaitu reliability item (validitas tiap indikator), composite reability, dan average variance extracted (AVE). Convergent validity digunakan untuk mengukur seberapa besar indikator yang ada dapat menerangkan dimensi. Artinya semakin besar convergent validity maka semakin besar kemampuan dimensi tersebut dalam menerapkan variabel latennya.

\section{a. Reliability Item}

Item reliabilitas atau biasa kita sebut dengan validitas indikator. Pengujian terhadap reability item (validitas indikator) dapat dilihat dari nilai loading factor (standardized loading). Nilai loading faktor ini merupakan besarnya korelasi antara antara setiap indikator dan konstraknya. Nilai loading factor diatas 0,7 dapat dikatakan ideal, artinya bahwa indikator tersebut dapat dikatakan valid sebagai indikator untuk mengukur konstrak. Meskipun demikian, nilai standardized loading factor diatas 0,5 dapat diterima. Sedangkan nilai standardized loading factor dibawah 0,5 dapat dikeluarkan dari model Chin (1998). Berikut adalah nilai reability item yang dapat dilihat pada kolom standardized loading, sebagaimana ditunjukkan pada Gambar 1.

Hasil perhitungan dapat dilihat bahwa loading untuk CF1 (item pertama pada dimensi Contextual or Situational Factor) sebesar 0,794; CF2 sebesar 0,706; CF3 sebesar 0,715 dan CF4 sebesar 0,731, serta CF5 sebesar 0,884. Loading factor untuk indikator pada Contextual or Situational Factor bernilai lebih dari 0,5 sehingga tidak perlu disisihkan. Selanjutnya pada indikator 
pada Leadership Factor LF1 sebesar 0,941; LF2 sebesar 0,799; LF3 sebesar 0,813; untuk LF4 sebesar 0,801; LF5 sebesar 0,915 dan LF6 sebesar 0,678. Loading factor untuk indikator pada Leadership Factor bernilai lebih dari 0,5 sehingga tidak perlu disisihkan.

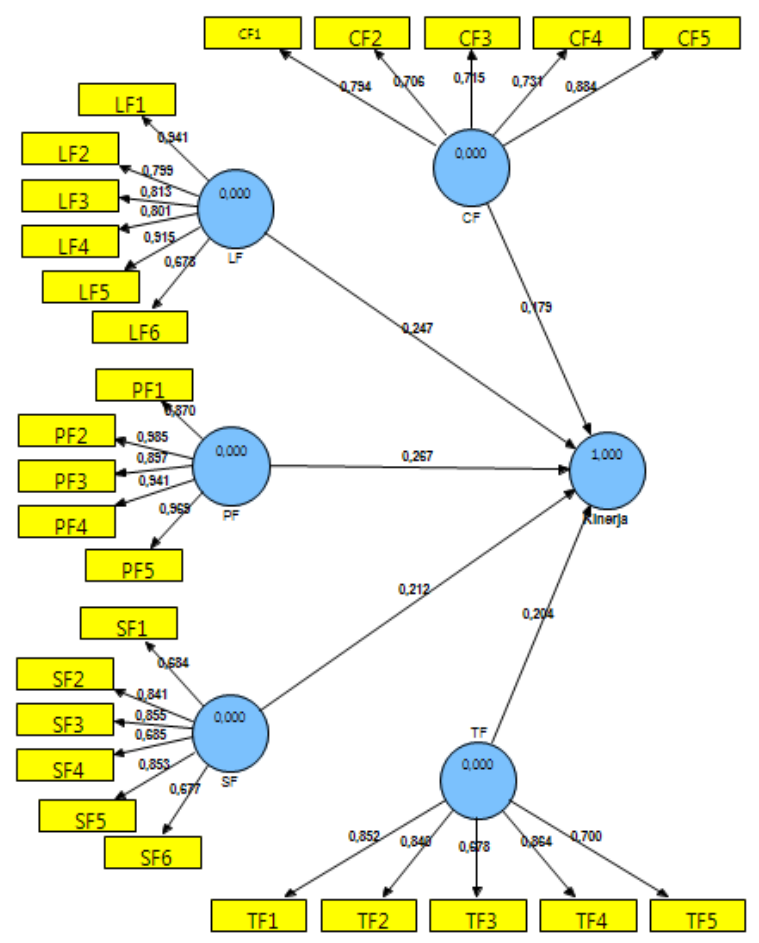

Gambar 1. Standardized Loading

Factor: Inner and Outer Model

Seluruh loading yang bernilai lebih dari 0,5 sehingga tidak perlu disisihkan. Dengan demikian, tiap indikator telah valid untuk menjelaskan masing-masing laten dimensinya yaitu pada team factor, personal factor, dan system factor. Selain menunjukkan validitas item dari masing-masing indikator, loading factor juga menunjukkan besarnya kontribusi tiap indikator pada faktornya. Untuk Personal Factor indikator yang memiliki loading paling besar adalah PF2; untuk Leadership Factor indikator yang memiliki loading paling besar adalah LF1; untuk Team Factor indikator yang memiliki loading paling besar adalah TF1; untuk System Factor indikator yang memiliki loading paling besar adalah SF3; sedangkan untuk Contextual Factor indikator yang memiliki loading paling besar adalah CF5.
Untuk keseluruhan indikator, yang memiliki loaidng factor paling besar adalah Personal Factor dengan loading factor sebesar 0,267, selanjutnya adalah leader factor dan system factor.

\section{b. Composite Reliability}

Statistik yang digunakan dalam composite reliability atau reabilitas konstrak adalah cronbach's alpha dan D.G rho (PCA). Nilai cronbach's alpha dan D.G rho (PCA) diatas 7,0 menunjukan konstrak memiliki reabilitas atau keterandalan yang tinggi sebagai alat ukur. Nilai batas 0,7 keatas berarti dapat diterima dan diatas 0,8 dan 0,9 berarti sangat memuaskan (Nunnally dan Bernstein, 1994 dalam Sofyan Yamin dan Heri Kurniawan, 2011: 19).

Tabel 15. Hasil Composite Reliability

\begin{tabular}{cc}
\hline & Composite Reliability \\
\hline CF & 0,878 \\
\hline LF & 0,929 \\
\hline PF & 0,971 \\
\hline SF & 0,896 \\
\hline TF & 0,892 \\
\hline
\end{tabular}

Sumber: Hasil Pengolahan Data, 2019

Tabel 15 di atas menunjukkan bahwa nilai composite reliability untuk contextual factor sebesar 0,878 leadership factor sebesar 0,929; Personal Factor sebesar 0,971 ; system factor sebesar 0,896 dan team factor sebesar 0,892. Kelima laten memperoleh nilai composite reliability di atas 0,7 sehingga dapat dikatakan kelima factor memiliki reabilitas atau keterandalan yang baik sebagai alat ukur.

\section{c. Average Variance Extracted (AVE)}

Average Variance Extracted (AVE) menggambarkan besaran variance yang mampu dijelaskan oleh item-item dibandingkan dengan varian yang disebabkan oleh error pengukuran. Standarnya adalah bila nilai AVE diatas 0,5 maka dapat dikatakan bahwa konstrak memiliki convergent validity yang baik. Artinya 
variabel laten dapat menjelaskan rata-rata lebih dari setengah variance dari indikatorindikatornya.

Tabel 16. Hasil Average Variance Extracted (AVE)

\begin{tabular}{cc}
\hline & AVE \\
\hline CF & 0,591 \\
\hline LF & 0,687 \\
\hline PF & 0,871 \\
\hline SF & 0,593 \\
\hline TF & 0,625 \\
\hline
\end{tabular}

Sumber: Hasil Pengolahan Data, 2019

Tabel 16 di atas menunjukkan bahwa nilai AVE untuk contextual factor sebesar 0,591 leadership factor sebesar 0,687; Personal Factor sebesar 0,871; system factor sebesar 0,593 dan team factor sebesar 0,625 . Kelimavariabel memiliki AVE yang berada di atas 0,5 sehingga konstrak memiliki convergent validity yang baik dimana variabel laten dapat menjelaskan rata-rata lebih dari setengah variance dari indikator-indikatornya

\section{Discriminant Validity}

Pemeriksaan discriminant validity dari model pengukuran reflektif yang dinilai berdasarkan cross loading dan membandingkan antara nilai AVE dengan kuadrat korelasi antar konstrak. Ukuran cross loading adalah adalah membandingkan korelasi indikator dengan konstraknya dan konstrak dari blok lain. Discriminant validity yang baik akan mampu menjelaskan variabel indikatornya lebih tinggi dibandingkan dengan menjelaskan varian dari indikator konstrak yang lain. Berikut adalah nilai discriminant validity untuk masingmasing indikator, sebagaimana ditunjukkan pada Tabel 17.

Tabel 17. Discriminant Validity

\begin{tabular}{cccccc}
\hline & CF & LF & PF & SF & TF \\
\hline CF1 & 0,794 & 0,512 & 0,563 & 0,543 & 0,646 \\
\hline CF2 & 0,706 & 0,509 & 0,569 & 0,552 & 0,656 \\
\hline CF3 & 0,715 & 0,523 & 0,605 & 0,561 & 0,653 \\
\hline CF4 & 0,731 & 0,533 & 0,613 & 0,566 & 0,674 \\
\hline CF5 & 0,884 & 0,584 & 0,699 & 0,546 & 0,683 \\
\hline LF1 & 0,709 & 0,941 & 0,710 & 0,702 & 0,807 \\
\hline LF2 & 0,476 & 0,799 & 0,559 & 0,476 & 0,583 \\
\hline
\end{tabular}

\begin{tabular}{cccccc}
\hline LF3 & 0,548 & 0,813 & 0,601 & 0,454 & 0,610 \\
\hline LF4 & 0,547 & 0,801 & 0,588 & 0,525 & 0,649 \\
\hline LF5 & 0,698 & 0,915 & 0,769 & 0,758 & 0,881 \\
\hline LF6 & 0,402 & 0,678 & 0,422 & 0,433 & 0,450 \\
\hline PF1 & 0,766 & 0,609 & 0,870 & 0,664 & 0,764 \\
\hline PF2 & 0,747 & 0,817 & 0,985 & 0,552 & 0,680 \\
\hline PF3 & 0,661 & 0,625 & 0,897 & 0,615 & 0,671 \\
\hline PF4 & 0,736 & 0,614 & 0,941 & 0,670 & 0,743 \\
\hline PF5 & 0,799 & 0,807 & 0,969 & 0,712 & 0,813 \\
\hline SF1 & 0,492 & 0,496 & 0,487 & 0,684 & 0,610 \\
\hline SF2 & 0,648 & 0,647 & 0,621 & 0,841 & 0,791 \\
\hline SF3 & 0,630 & 0,613 & 0,618 & 0,855 & 0,777 \\
\hline SF4 & 0,462 & 0,461 & 0,492 & 0,685 & 0,585 \\
\hline SF5 & 0,600 & 0,531 & 0,530 & 0,853 & 0,730 \\
\hline SF6 & 0,458 & 0,398 & 0,404 & 0,677 & 0,552 \\
\hline TF1 & 0,749 & 0,690 & 0,674 & 0,739 & 0,852 \\
\hline TF2 & 0,744 & 0,660 & 0,689 & 0,759 & 0,840 \\
\hline TF3 & 0,562 & 0,568 & 0,520 & 0,589 & 0,678 \\
\hline TF4 & 0,732 & 0,712 & 0,653 & 0,779 & 0,864 \\
\hline TF5 & 0,601 & 0,603 & 0,565 & 0,611 & 0,700 \\
\hline Sub:
\end{tabular}

Sumber: Hasil Pengolahan Data, 2019

Tabel 17 di atas menunjukkan bahwa nilai discriminant validity atau loading factor untuk CF1 adalah 0,794. Korelasi indikator tersebut pada contextual factor lebih besar dibandingkan pada faktor lainnya, yaitu pada leadership factor 0,512; selanjutnya pada Personal Factor sebesar 0,563; system factor sebesar 0,543 dan pada team factor sebesar 0,646. Demikian juga untuk CFA hingga CF5 yang menunjukkan korelasi terbesar pada contextual factor disbandingkan dengan factor lainnya.

Semua nilai loading factor untuk tiap dimensi/faktor memiliki korelasi yang lebih tinggi dengan faktornya sendiri dibandingkan dengan dimensi/factor lainnya. Demikian pula dengan indikator-indikator tiap dimensi/faktornya. Ini menunjukkan bahwa penempatan indikator pada tiap faktornya telah tepat.

\section{KESIMPULAN}

Penelitian mengenai faktor-faktor kinerja TNI di Kodim 0618/BS Kota Bandung menunjukkan bahwa hal yang paling mempengaruhi dalam kinerja TNI di Kodim 0618/BS adalah personal factor, yaitu sebesar $24,05 \%$ hal tersebut disebabkan dalam diri TNI itu sendiri sudah ada komitmen yang sangat kuat hal tersebut 
ditandai bahwa ternyata TNI adalah profesi yang mereka cita-citakan serta latar belakang keluarga yang berasal dari keluarga TNI juga. Selain itu, faktor leadership juga sangat mempengaruhi faktor kinerja TNI di Kodim 0618/BS Kota Bandung yaitu sebanyak 21,84\% dimana system pada TNI itu sendiri yaitu sistem komando yang mempengaruhi hal tersebut.

\section{DAFTAR PUSTAKA}

\section{Buku:}

Arep, Ishak dan Tanjung, Hendri. 2003. Manajemen Sumber Daya Manusia. Jakarta: Universitas Trisakti.

Creswell, J. W. 2010. Research Design: Pendekatan Kualitatif, Kuantitatif, dan Mixed. Yogyakarta: PT Pustaka Pelajar.

Davis, Keith dan Newstrom. 2001. Perilaku Dalam Organisasi. Edisi Ketujuh. Jakarta: Erlangga.

Kreitner, Robert dan Kinicki, Angelo. 2003. Perilaku Organisasi. Penterjemah: Early Suandy. Jakarta: Salemba Empat.

Kusriyanto, Bambang. 1991. Meningkatkan Produktivitas Karyawan. Jakarta: PT. Pustaka Binaman Pressindo.

Nitisemito, Alex S. 1992. Manajemen dan Sumber Daya Manusia. Yogyakarta: BPFE UGM.

Nuraini, T. 2013. Manajemen Sumber Daya Manusia. Pekanbaru: Yayasan Aini Syam.

Raharjo, Satjipto. 1999. Kerajinan Pandai Besi Daerah Riau. Pekanbaru: Departemen Pendidikan dan Kebudayaan.

Sedarmayanti. 2001. Sumber Daya Manusia dan Produktivitas Kerja. Bandung: Mandar Maju.

Siagian, Sondang P. 2010. Manajemen Sumber Daya Manusia. Jakarta: Bumi Aksara.
Sudarmanto. 2009. Kinerja dan Pengembangan Kompetensi SDM. Yogyakarta: Pustaka Pelajar.

Sugiono. 2011. Metode Penelitian Kuantitatif, Kualitatif dan R\&D. Bandung: CV Alfabeta.

Syamsu, Yusuf. 2000. Psikologi Perkembangan Anak \& Remaja. Bandung: Remaja Rosdakarya.

Wibowo. 2011. Manajemen Kinerja. Jakarta: PT. Raja Grafindo Persada.

Wusanto, Ignasius. 2009. Dasar-dasar Ilmu Organisasi. Edisi Kedua. Yogyakarta: Andi.

Jurnal:

Leblebici, D. 2012. "Impact of Workplace Quality on Employee Productivity: Case Study of a Bank in Turkey". Journal of Business Economics and Finance, 1, 38-49. 